С. Ю. Штриголь, В. В. Цивунін, І. М. Риженко, Л. В. Деримедвідь, К. Г. Щокіна, Я. О. Бутко, В. П. Вереітинова, О. В. Товчига, Г. В. Бєлік, О. В. Кудіна, Т. О. Куценко, А. В. Таран, А. В. Матвійчук, Ю. В. Столєтов, В. А. Уланова, О. О. Койро, Л. Б. Іванцик, М. В. Зупанець

\title{
Взаємозв'язок показників поточної та екзаменаційної успішності вивчення фармакології здобувачами вищої фармацевтичної освіти як індикатор для моніторингу якості освіти
}

Національний фармацевтичний університет

Міністерства охорони здоров'я України, м. Харків

Ключові слова: фармакологія, методи перевірки та оцінки успішності, результати навчання, здобувачі вищої освіти, фармацевти, процесна модель діяльності

У системі підготовки майбутніх спеціалістів фармації фармакологія займає перехідну позицію між базовими фундаментальними (біологія, фізіологія 3 основами анатомії людини, патофізіологія, біологічна хімія, мікробіологія 3 основами імунологіi) і спеціальними профільними предметами (фармакотерапія, клінічна фармація, фармацевтична опіка). Цілком обгрунтовано фармакологія вважається інтегральною дисципліною, що формує професійне мислення як провізорів (фармацевтів), так і лікарів [1-6]. Тому не викликає сумнівів важливість постійного вдосконалення форм і методів викладання фармакології в закладах вищої медичної та фармацевтичної освіти, а також визначення успішності засвоєння матеріалу дисципліни як універсального індикатора ефективності навчання. 3 огляду на стійку тенденцію до зростання частки іноземних громадян у структурі контингенту здобувачів вищої освіти (3ВО) постає питання щодо їхніх особливостей порівняно з вітчизняними ЗВО в аспекті академічної успішності як предиктора трансформації знань, умінь і навичок у компетентності. Це

(C) Колектив авторів, 2020 питання важливе також як маркер ефективності різних форм і методів навчання окремих контингентів 3 ВО.

Мета дослідження - оцінити успішність вивчення фармакології майбутніми спеціалістами фармації (вітчизняними та іноземними 3ВО) за результатами аналізу підсумкових оцінок, балів за письмовий курсовий іспит і відсотків правильних відповідей з дисципліни на ліцензійному тестовому іспиті КРОК-1 «Фармація», а також розробити процесну модель діяльності з підвищення якості підготовки з фармакології.

Матеріали та методи. У дослідженні проаналізовано кількісні результати вимірювання успішності вивчення фармакології 473 ЗВО (266 вітчизняних i 207 іноземних) третього курсу денної форми навчання, що вивчали дисципліну на кафедрі фармакології Національного фармацевтичного університету (опорної в системі фармацевтичної освіти України) протягом 2018/2019 навчального року та мали допуск до екзаменаційної сесії.

Серед вітчизняних ЗВО 191 особа навчається за освітньою програмою «Фармація», 21 і 19 - мають середню спеціальну фармацевтичну або медичну освіту відповідно, 15 - навчаються за освітньою програмою «Клінічна фармація» і 20 - здобувають освіту за програмою «Технологія парфумерно-косметичних засобів» . 
Іноземний контингент $3 \mathrm{BO}$ (освітня програма «Фармація») розподілився таким чином: 15 осіб - із країн ближнього зарубіжжя (Білорусь, Туркменістан, Узбекистан) 3 російською мовою навчання, 192 - із країн далекого зарубіжжя (Марокко, Сгипет, Ліван, Сирія, Ірак, Франція, Туреччина, Танзанія, Гана, Нігерія, Конго, Мадагаскар, Ямайка): 129 - 3 російською мовою навчання та 63 - з англійською мовою навчання. Їхнє порівняння важливе 3 огляду на етнопсихологічні особливості ЗВО з різних країн. В окремих випадках для іноземних $3 В 0$ також має значення навчання нерідною мовою. Заняття 3 фармакології в ЗВО усіх зазначених контингентів вели одні й ті самі викладачі, які дотримувались уніфікованих критеріїв оцінювання знань. Великий контингент 3ВО дозволяе максимально об'єктивізувати результати, нівелювати вплив випадкових чинників і висвітлити загальні закономірності.

Як маркери успішності вивчення дисципліни визначено:

- поточний підсумковий рейтинг, що являє собою середне арифметичне рейтингової суми балів за осінній та весняний семестри - максимум 100;

- критерії оцінювання успішності студентів на кожному занятті, модульному контролі знань є уніфікованими;

- оцінку за курсовий іспит з фармакології - максимум 100 (далі - іспит);

- відсоток правильних відповідей 3 дисципліни «Фармакологія» на ліцензійному тестовому іспиті КРОК-1 «Фармація» [7] - максимум 100 (далі - КРОК-1).

Курсовий іспит проводився в письмовій формі. Екзаменаційний білет складався 34 питань. Перше питання зі загальної фармакології. Друге - 3 характеристики окремих лікарських препаратів різних груп за схемою «групова належність - фармакологічні ефекти - показання до застосування». Третє - комплексне, що вимагає вказати назви препаратів різних груп, механізм їхньої дії, певний фармакологічний ефект, показання, прояв побічної дії, протипоказання до застосування тощо. Четверте - корекція лікарського рецепта. На відміну від тестового ліцен- зійного іспиту «КРОК-1», у курсовому іспиті всі питання $є$ відкритого типу. 3 їхнім переліком та критеріями оцінювання ЗВО заздалегідь ознайомлені (сайт кафедри, інформаційний стенд).

100-бальна система оцінювання за кожного виду контролю знань створює підставу для певної уніфікації балів і зручного зіставлення відповідних результатів.

Статистичну обробку результатів виконували за допомогою пакета програм STATISTICA 8.0 for Windows. Перевіряли характер розподілу за критерієм ANOVA. Розраховували середнє значення, стандартну похибку середнього, довірчий інтервал (р). Достовірність відмінностей між групами порівняння оцінювали за критеріями Стьюдента (t) і Манна-Вітні (U) залежно від характеру розподілу даних. Достовірними вважали відмінності в разі $\mathrm{p}<$ 0,05. Закономірності зв'язку між показниками поточний рейтинг - іспит (П-I), поточний рейтинг - КРОК-1 (П-К), іспит - КРОК-1 (І-К) аналізували за коефіцієнтом кореляції Спірмена

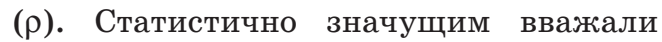
зв'язок у разі $\mathrm{p}<0,05$.

У створенні процесної моделі з підвищення якості підготовки ЗВО з фармакології використовували рекомендації ДСТУ ISO 9001:2015 [8].

Результати та їх обговорення. Результати успішності вивчення фармакології вітчизняними $3 \mathrm{BO}$ наведено в таблиці 1.

Як свідчать дані таблиці 1 , у сукупній вибірці відсутні суттєві відмінності між поточним рейтингом та оцінкою за іспит при достовірно вищому показникові правильних відповідей тесту КРОК-1 щодо поточного рейтингу та оцінки за іспит. Найкращі результати на всіх етапах контролю якості знань продемонстрували $3 \mathrm{BO}$ освітньої програми «Фармація», які мають середню спеціальну фармацевтичну освіту, та освітньої програми «Клінічна фармація».

Кореляційний аналіз (рис. 1) вказує на наявність статистично значущого додатного зв'язку середньої сили в парах П-I $(\rho=0,54), \Pi-K(\rho=0,62)$, I-K $(\rho=0,48)$. Коливання зв'язку в парі П-I в окремих групах ЗВО різних 
Успішність вивчення фарлакологї̈ вітчизнянили здобувачали вищой освіти $(M \pm m)$

\begin{tabular}{|c|c|c|c|}
\hline $\begin{array}{c}\text { Освітня програма, } \\
\text { особливості контингенту }\end{array}$ & $\begin{array}{l}\text { Поточний } \\
\text { рейтинг }\end{array}$ & Іспит & КРОК-1 \\
\hline $\begin{array}{l}\text { «Фармація» (без середньої } \\
\text { спеціальної освіти), n = } 191\end{array}$ & $76,03 \pm 0,71$ & $75,72 \pm 0,75$ & $82,14 \pm 0,93^{\star * *, \ldots \#}$ \\
\hline $\begin{array}{l}\text { «армація» (середня спеціальна } \\
\text { фармацевтична освіта), } \mathrm{n}=21\end{array}$ & $81,48 \pm 2,17$ & $83,33 \pm 2,62$ & $91,27 \pm 1,43^{\star \star *, \#}$ \\
\hline $\begin{array}{l}\text { «армація» (середня спеціальна } \\
\text { медична освіта), n = } 19\end{array}$ & $72,42 \pm 1,69$ & $79,16 \pm 2,44^{\star}$ & $83,08 \pm 1,84^{\star * *}$ \\
\hline «Клінічна фармація», n = 15 & $79,13 \pm 2,55$ & $87,13 \pm 1,02^{\star \star}$ & $85,09 \pm 1,46^{\star}$ \\
\hline $\begin{array}{l}\text { «Технологія парфумерно-косме- } \\
\text { тичних засобів», n = } 20\end{array}$ & $72,0 \pm 1,78$ & $75,05 \pm 2,88$ & $74,78 \pm 2,54$ \\
\hline Разом, $n=266$ & $76,08 \pm 0,60$ & $77,16 \pm 0,67$ & 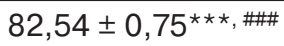 \\
\hline
\end{tabular}

Прилітка. Статистично значущі відлінності з поточним рейтингол: *p $<0,05$, **p $<0,01$, ***p $<0,001$;

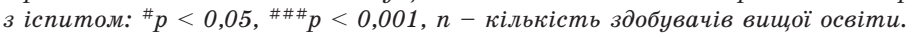

освітніх програм були незначними. Більш тісний додатний зв'язок у парі П-К у всього обговорюваного контингенту як у цілому, так і в більшості груп, вочевидь, підкреслює досить ефективне використання фундаментальних знань тими ЗВО, які виявили вищу успішність протягом обох семестрів вивчення фармакології, при відповідях на тестові питання ліцензійного іспиту КРОК-1.

Ця закономірність спостерігається й у більшості вітчизняних 3 ВО інших контингентів. Зокрема, у ЗВО за освітньою програмою «Технологія парфумерно-косметичних засобів" зв'язок у парі П-К був найсильнішим ( $\rho=0,72, \mathrm{p}<$ 0,05). На відміну від пар П-І та П-К, зв'язок у парі I-К був дещо слабше.

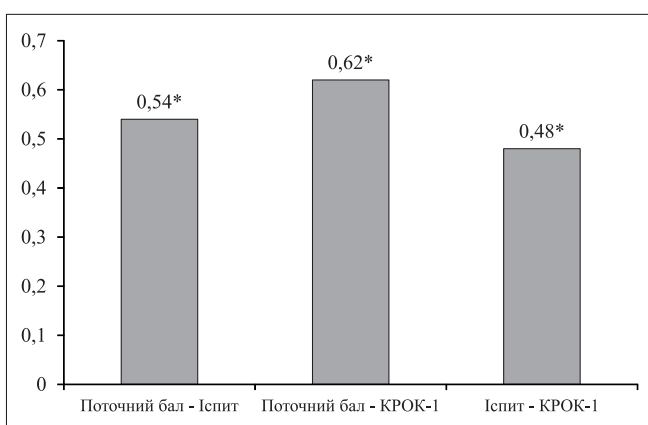

Рис. 1. Кореляційний зв'язок ліж узагальненили балали в оцінюванні успішності вивчення фарлакологї вітчизнянили здобувачами вищої освіти

Прилітка. По осі ординат - коефіцієнт кореля иії Спірлена ( $\rho)$, *статистично значущий зв'язок $(p<0,05)$.
Узагальнені результати аналізу успішності вивчення фармакології іноземними здобувачами вищої освіти наведено в таблиці 2.

Порівняння даних таблиць 1 i 2 демонструє, що в цілому успішність вивчення фармакології в іноземних 3ВО $\mathrm{\epsilon}$ дещо нижчою, ніж у вітчизняних. Дані таблиці 2 свідчать, що в загальній вибірці іноземних ЗВО оцінки за курсовий іспит статистично значуще вище порівняно 3 поточним рейтингом. Це особливо характерно для російськомовних ЗВО з країн ближнього зарубіжжя, що, вочевидь, пов'язано з більшою систематизацією знань перед курсовим іспитом для цього відносно невеликого контингенту. На іспиті КРОК-1 результат цих 3ВО, навпаки, практично відповідав поточному рейтингу. Результат іспиту КРОК-1 у більшості випадків був нижчим, ніж бал за курсовий іспит, і практично дорівнював або поступався (в англомовних 3ВО) поточному рейтингу.

Кореляційний аналіз (рис. 2) вказуе на наявність статистично значущих додатних зв'язків середньої сили в парах П-І $(\rho=0,68), \Pi-К(\rho=0,43)$, I- $\kappa$ $(\rho=0,39)$.

Зв’язок у парі П-І у всій вибірці наближається до сильного, а в російськомовних 3 ВО 3 країн ближнього зарубіжжя та в англомовних був достовірно сильним ( $\rho=0,75$ і $\rho=0,74$ відповідно, $\mathrm{p}<0,05)$. Порівняно з результатами вітчизняних студентів, де відповід- 
Успішність вивчення фармакології інозелними здобувачами вищої освіти $(M \pm m)$

\begin{tabular}{|l|c|c|c|}
\hline \multicolumn{1}{|c|}{$\begin{array}{c}\text { Освітня програма, } \\
\text { особливості контингенту }\end{array}$} & $\begin{array}{c}\text { Поточний } \\
\text { бал }\end{array}$ & Іспит & КРОК-1 \\
\hline $\begin{array}{l}\text { «Фармація» (країни ближнього зару- } \\
\text { біжжя, російська мова навчання), } \mathrm{n}=15\end{array}$ & $70,77 \pm 1,33$ & $81,87 \pm 2,51^{\star \star \star}$ & $67,94 \pm 5,72^{\#}$ \\
\hline $\begin{array}{l}\text { «Фармація» (країни далекого зарубіж- } \\
\text { жя, російська мова навчання), } \mathrm{n}=129\end{array}$ & $68,61 \pm 0,74$ & $70,13 \pm 1,02$ & $68,38 \pm 1,41$ \\
\hline $\begin{array}{l}\text { «Фармація» (країни далекого зарубіж- } \\
\text { жя, англійська мова навчання), } \mathrm{n}=63\end{array}$ & $70,73 \pm 1,36$ & $74,54 \pm 1,73$ & $64,71 \pm 1,55^{\star *, \ldots \#}$ \\
\hline Разом, $\mathrm{n}=207$ & $69,41 \pm 0,63$ & $72,32 \pm 0,87^{\star \star}$ & $67,23 \pm 1,08^{\# \#}$ \\
\hline
\end{tabular}

Прилітка. Статистично значущі відлінності з поточним рейтингом: **p $<0,01$, ***p <0,001;

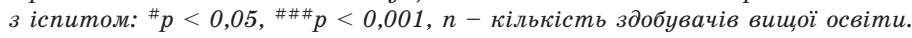

ний коефіцієнт кореляції становив 0,54 у всій вибірці (рис. 1) з коливаннями в межах 0,43-0,63, це свідчить про більшу ймовірність високого результату на курсовому іспиті з підвищенням поточного рейтингу. Зв'язки в парах П-К і $\mathrm{I}-\mathrm{K}$, навпаки, значно поступаються таким у вітчизняних студентів. Це може свідчити про менше використання фундаментальних знань під час підготовки та складання іспиту КРОК-1 із переважанням заучування правильних відповідей на типові тестові завдання.

Підвищення оцінки на іспиті порівняно з поточним рейтингом у більшості досліджуваних контингентів ЗВО можна вважати закономірним явищем, оскільки систематична робота протягом двох семестрів сприяє формуванню цілісного, інтегрованого розуміння фармакології наприкінці вивчення цієї навчальної дисципліни.

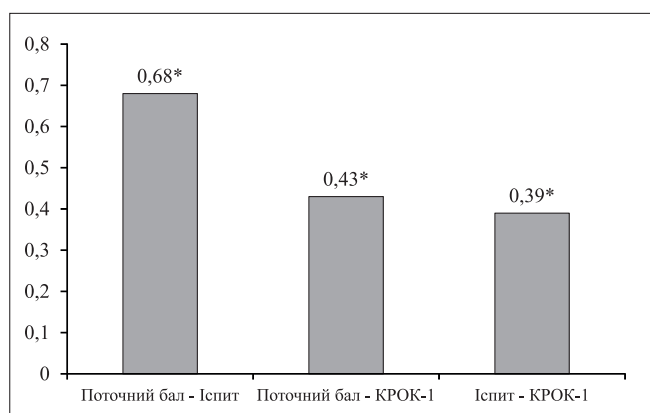

Рис. 2. Кореляиійний зв'язок між узагальненили балали в оцінюванні успішності вивчення фарлакологї інозелнили здобувачали вищой освіти

Прилітка. По осі ординат - коефіцієнт кореляиії Спірлена ( $\rho)$, *статистично значущий зв'язок $(p<0,05)$.
Виявлені відмінності між успішністю окремих контингентів, закономірності кореляційних зв'язків поточної та екзаменаційної успішності, особливо щодо іспиту КРОК-1, є основою для визначення напрямів удосконалення викладання фармакології. Перш за все це стосується іноземних ЗВО.

Алгоритм заходів передбачає перш за все постійне підвищення мотивації до навчання. Крім того, необхідно вдосконалювати форми й методи викладання, посилювати міждисциплінарні зв'язки, дедалі більше враховувати етнопсихологічні особливості іноземних громадян, поглиблювати індивідуальний підхід.

Особливо важливе значення має порівняльне комплексне психологопедагогічне дослідження різних контингентів 3ВО. Його результати сприятимуть визначенню зазначених особливостей, виявленню «вузьких місць» як мішеней педагогічного впливу, допоможуть краще долати формальне ставлення окремих контингентів 3ВО до навчання та формувати професійні компетентності, які $€$ індикаторами, що дозволяють визначити готовність ЗВО до подальшого професійного життя.

Доцільно також ширше залучати ЗВО до науково-дослідної діяльності з фармакології, що сприятиме кращому узагальненню знань i навичок їx використання. Розвиток дослідницьких умінь ЗВО є одним із основних чинників підготовки висококваліфікованих кадрів закладів вищої освіти 
України [10]. Наразі студентське наукове товариство кафедри фармакології налічує понад 20 активних учасників, більшість з яких навчаються на 3 курсі.

Привертає увагу така форма роботи, як олімпіади з фармакології зі заохоченням кращих ЗВО. Зокрема, у 2019/20 навчальному році в I етапі Всеукраїнської студентської олімпіади 3 фармакології НФаУ взяли участь 39 вітчизняних і 24 закордонних ЗВО (14 англомовних і 10 російськомовних). Участь в олімпіадах сприяє інтеграції знань з різних розділів фармакології, навичок їхнього оперативного використання для розв'язання конкретних завдань, підвищує рівень компетентності ЗВО з фармакології. Упродовж 2017-2019 навчальних років вітчизняні ЗВО гідно репрезентували НФаУ на II етапі Всеукраїнської студентської олімпіади з фармакології, демонструючи високі результати.

У рамках впровадження запропонованих заходів доцільно періодично виконувати повторне порівняльне дослідження успішності ЗВО з фармакології з визначенням кореляції між поточним рейтингом, курсовим іспитом і тестовим іспитом КРОК-1. Посилення прямого зв'язку між результатами зазначених видів контролю знань у кожній парі $€$ маркером ефективності вивчення фармакології, спадкоємності знань і практичних навичок.

На підставі вищенаведеного розроблено процесну модель діяльності щодо вдосконалення вивчення фармакології відповідно до стандартів ISO 9001:2015, які впроваджено в НФаУ [9]. Цю процесну модель наведено на рисунку 3 .

Запропоновано управлінські, основні та допоміжні процеси, що забезпечують якість підготовки ЗВО з фармакології.

До управлінських процесів належать управління розвитком (підпроцесами $\epsilon$ стратегічне планування, вдосконалення навчальних програм), управління функціонуванням кафедри фармакології (підпроцесами є менеджмент процесів i ресурсів, аналіз і прийняття рішень), а також процеси моніторингу та вимірювань кінцевих результатів.

Проте останні доцільно виокреми- ти, оскільки вони мають відносно самостійне значення у функції управління, сприяючи інформаційному забезпеченню та зворотному зв'язку, та скеровують діяльність кафедри фармакології на досягнення бажаних результатів.

У рамках основних процесів виокремлено навчальний процес, а також такі форми роботи, як залучення ЗВО до науково-дослідної діяльності та олімпіад з фармакології.

Допоміжні процеси створюють необхідні умови для реалізації основних процесів. До допоміжних процесів доцільно віднести вдосконалення навчально-методичного забезпечення, форм і методів навчання на кафедрі фармакології; покращання матеріально-технічного та кадрового забезпечення, у тому числі англомовними викладачами (значна частка викладачів кафедри фармакології володіє англійською мовою на рівні В2, що підтверджено відповідним сертифікатом, або має другу вищу освіту 3 англійської мови); психолого-педагогічне дослідження ЗВО 3 визначенням їхньої мотивації до високоякісного оволодіння фармакологією, що створює умови для індивідуалізації навчання ЗВО 3 відносно невисокою мотивацією. Важливим підпроцесом навчально-методичного забезпечення є створення довідкової літератури, яка сприяє підвищенню рівня знань з англійської мови професійного спрямування, оскільки єдиний державний кваліфікаційний іспит для здобувачів ступеня вищої освіти магістр за спеціальностями галузі знань «22 Охорона здоров'я» передбачає не лише інтегрований тестовий іспит КРОК-1, але й іспит 3 англійської мови професійного спрямування [11]. На цьому шляху в 2019 році створено англо-український і українсько-англійський словник із фармацевтичної термінології «КРОК 1. Фармація»= EnglishUkrainian and Ukrainian-English Dictionary of Pharmacy Terminology «KROK 1 . Pharmacy» [12], один із розділів якого присвячено фармакологічній лексиці та термінології.

Запропонований алгоритм оцінки показників успішності вивчення фар- 


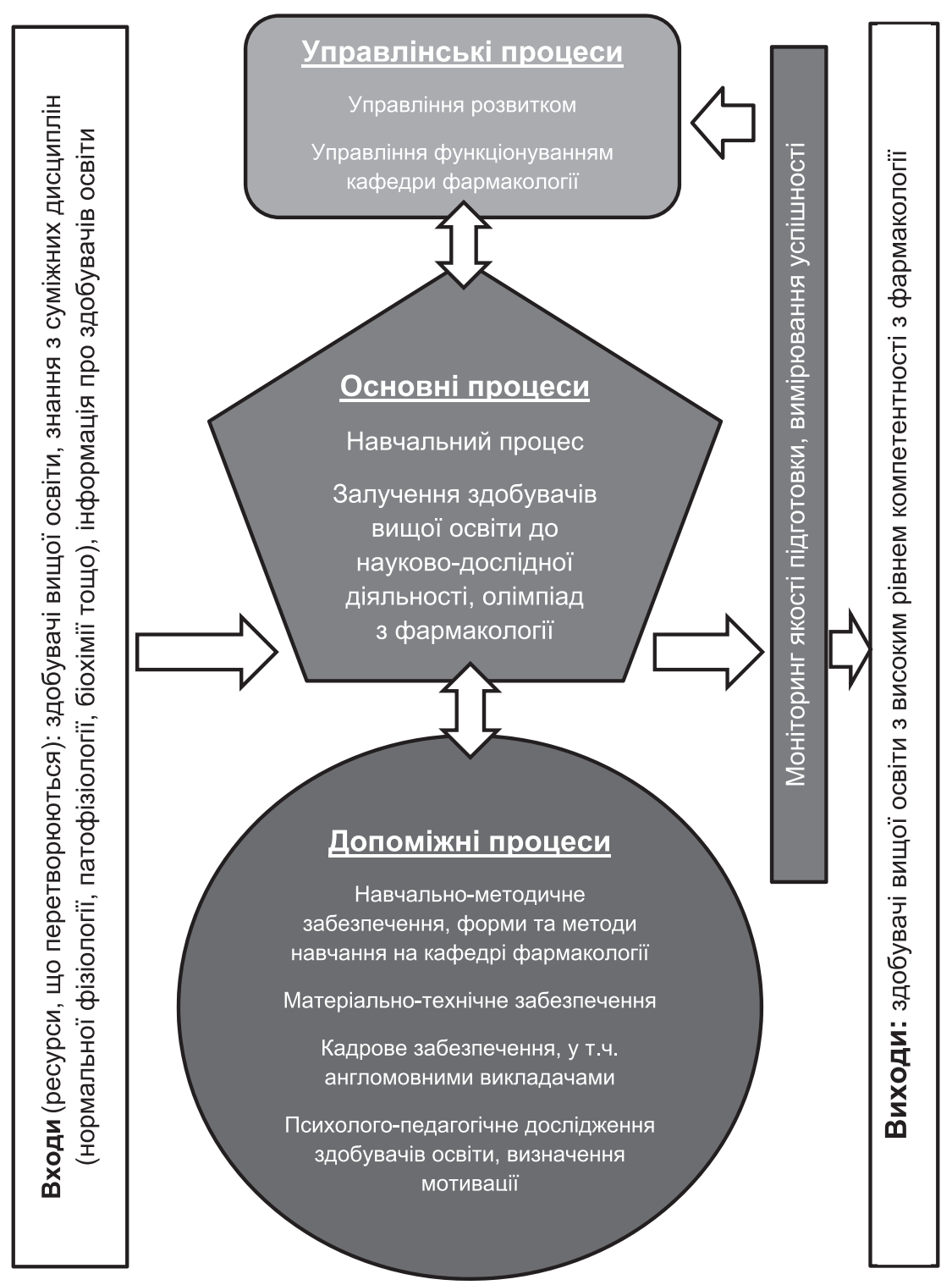

Рис. 3. Процесна модель діяльності щодо підвищення якості підготовки здобувачів вищой фарлацевтичної освіти з фарлакологї

макології та процесна модель діяльності 3 підвищення якості підготовки 3 цієї навчальної дисципліни можуть бути використані кафедрами фармакології закладів вищої освіти України.

\section{Висновки}

Досліджено успішність вивчення фармакології майбутніми спеціалістами фармації за результатами аналізу поточного рейтингу, оцінки за письмовий іспит і кількості правильних відповідей з дисципліни на ліцензійному тестовому іспиті КРОК-1. Загалом, вітчизняні здобувачі вищої фармацевтичної освіти докладають найбільших зусиль до складання іспиту КРОК-1, що встановлено за кращими результатами іспиту КРОК-1 порівняно з поточним рейтингом i курсовим іспитом. Іноземні здобувачі вищої фармацевтичної освіти мають нижчу поточну успішність і в цілому гірше, ніж вітчизняні, складають ліцензійний іспит КРОК-1. Кореляційний аналіз показав статистично значущі взаємо- 
зв'язки між поточним рейтингом, курсовим іспитом і відсотком правильних відповідей тесту КРОК-1 з фармакологіï. Проте у вітчизняних здобувачів вищої освіти зв'язки між поточним рейтингом і результатом іспиту КРОК-1 й результатами курсового та ліцензійного іспитів сильніші, ніж в інозем- них, що може свідчити про більшу увагу до фундаментальних знань при підготовці та складанні іспиту КРОК-1. Запропоновано процесну модель діяльності з покращання успішності вивчення фармакології та підвищення фармакологічної компетентності майбутніх фармацевтів.

1. Learning analytics in medical education assessment: the past, the present, and the future. T. Chan, S. Sebok-Syer, B. Thoma et al. AEM Education and Training. 2018. V. 2 (2). P. 178-187.

2. Сліпчук В. Л. Підготовка фахівців фармацевтичної галузі в Україні в умовах євроінтеграції. Неперервна професійна освіта: теорія і практика. 2014. № 3-4. С. 63-68.

3. Горчакова Н. О., Савченко Н. В., Шумейко О. В. Інтеграція фармакології з медичною та біологічною хімією. Вісник проблем біології і медицини. 2015. № 1 (117). С. 55-61.

4. Heck T. G. Pharmacology and Exercise: An Essential Discipline and Research Area in Health Courses. J Nov Physiother. 2013. № 3. P. 128.

5. Чечотіна С. Ю. Актуальність упровадження міждисциплінарної інтеграції при вивченні фармакології. Український стоматологічний альманах. 2013. № 4. С. 86-89.

6. Анализ качества самоподготовки студентов III курса по учебной дисциплине «Фармакология». Е. Ф. Гайсина, Н. В. Изможерова, В. М. Бахтин, Ю. С. Тагильцева. On line scientific \& educational Bulletin «Health and Education Millennium». 2019. V. 21. № 5. C. 24-29.

7. Наказ Міністерства освіти та науки України від 29.07.2004 № 629 «Про затвердження складових галузевих стандартів вищої освіти зі спеціальностей 7.110201 «Фармація», 7.110202 «Технологія парфумерно-косметичних засобів», 7.110204 «Технологія фармацевтичних препаратів», 7.110206 «Клінічна фармація» напряму підготовки 1102 «Фармація» та спеціальності 6.110100 «Лабораторна діагностика» напряму підготовки 1101 «Медицина». Електронний ресурс. URL: https://www.testcentr.org.ua/docs/ND/moz-29.07.2004-629.pdf.

8. ДСТУ ISO 9001:2015 Системи управління якістю. Вимоги (ISO 9001:2015, IDT). Електронний pecypc. URL: https://khoda.gov.ua/image/catalog/files/\%209001.pdf.

9. Національний фармацевтичний університет Міністерства охорони здоров'я України. Система управління якістю університету. Електронний ресурс. URL: https://nuph.edu.ua/sistema-upravlinnya-yakistyu-universit/

10. Максименко С. Д., Філоненко М. М. Методичні рекомендації «Науково-дослідницька діяльність студентів». Київ : Центр учбової літератури. 2013. 64 с.

11. Центр тестування при Міністерстві охорони здоров'я України. ЄДКІ. Електронний ресурс. URL:https://www.testcentr.org.ua/uk/edki.

12. Англо-український та українсько-англійський словник із фармацевтичної термінології «КРОК 1. Фармація» = English-Ukrainian and Ukrainian-English Dictionary of Pharmacy Terminology «KROK 1. Pharmacy»: прибл. 15500 термінів. Уклад.: А. А. Котвіцька, А. І. Федосов, Т. В. Крутських, Т. М. Гонтова, І. С. Гриценко, В.І.Кабачний, Н. М. Кононенко, В.М.Кравченко, Н. І. Філімонова, Л. А. Шемчук, С. Ю. Штриголь, Л. Г. Буданова. Харків : НФаУ, 2019.248 с.

С. Ю. Штриголь, В. В. Цивунін, І. М. Риженко, Л. В. Деримедвідь, К. Г. Щокіна, Я. О. Бутко, В. П. Вереітинова, О. В. Товчига, Г. В. Бєлік, О. В. Кудіна, Т. О. Куценко, А. В. Таран, А. В. Матвійчук, Ю. В. Столєтов, В. А. Уланова, О. О. Койро, Л. Б. Іванцик, М. В. Зупанець

Взаємозв'язок показників поточної та екзаменаційної успішності вивчення фармакології здобувачами вищої фармацевтичної освіти як індикатор для моніторингу якості освіти

У системі підготовки майбутніх спеціалістів фармації фармакологія займає перехідну позицію між базовими фундаментальними (біологія, фізіологія з основами анатомії людини, патофізіологія, біологічна хімія, мікробіологія з основами імунології) та спеціальними профільними предметами (фармакотерапія, клінічна фармація, фармацевтична опіка). Цілком обґрунтовано фармакологія вважається інтегральною дисципліною, що формує професійне мислення як провізорів (фармацевтів), так і лікарів. Тому не викликає сумнівів важливість постійного вдосконалення методик викладання фармакології в закладах вищої медичної та фармацевтичної освіти, а також визначення успішності засвоєння матеріалу дисципліни як універсального індикатора ефективності навчання.

Мета дослідження - оцінити успішність вивчення фармакології майбутніми спеціалістами фармації (вітчизняними та іноземними здобувачами вищої освіти) за результатами аналізу підсумкових оцінок, балів за письмовий курсовий іспит і відсотків правильних відповідей з дисципліни на ліцен- 
зійному тестовому іспиті КРОК-1 «Фармація», а також розробити процесну модель діяльності з підвищення якості підготовки з фармакології.

Встановлено, що в цілому вітчизняні здобувачі вищої фармацевтичної освіти докладають найбільших зусиль до складання іспиту КРОК-1, що визначено за кращими результатами іспиту КРОК-1 порівняно з поточним рейтингом і курсовим іспитом. Іноземні здобувачі вищої фармацевтичної освіти мають нижчу поточну успішність і гірше, ніж вітчизняні, складають ліцензійний іспит КРОК-1. Кореляційний аналіз показав статистично значущі взаємозв'язки між поточним рейтингом, курсовим іспитом і відсотком правильних відповідей тесту КРОК-1 з фармакології. Проте у вітчизняних здобувачів вищої освіти зв'язки між поточним рейтингом і результатом іспиту КРОК-1 й результатами курсового та ліцензійного іспитів сильніші, ніж в іноземних, що може свідчити про більшу увагу до фундаментальних знань у процесі підготовки та складанні іспиту КРОК-1. Запропоновано процесну модель діяльності з покращання успішності вивчення фармакології та підвищення фармакологічної компетентності майбутніх фармацевтів відповідно до стандартів ISO 9001:2015.

Ключові слова: фармакологія, методи перевірки та оцінки успішності, результати навчання, здобувачі вищої освіти, фармацевти, процесна модель діяльності

\section{С. Ю. Штрыголь, В. В. Цывунин, И. М. Рыженко, Л. В. Деримедведь, \\ Е. Г. Щекина, Я. А. Бутко, В. П. Вереитинова, О. В. Товчига, Г. В. Белик, \\ О. В. Кудина, Т. А. Куценко, А. В. Таран, А. В. Матвийчук, Ю. В. Столетов, \\ В. А. Уланова, О. О. Койро, Л. Б. Иванцык, М. В. Зупанец \\ Взаимосвязь показателей текущей и экзаменационной успешности изучения фармакологии соискателями высшего фармацевтического образования как индикатор для мониторинга качества образования}

В системе подготовки будущих специалистов фармации фармакология занимает переходное положение между базовыми фундаментальными (биология, физиология с основами анатомии человека, патофизиология, биологическая химия, микробиология с основами иммунологии) и специальными профильными предметами (фармакотерапия, клиническая фармация, фармацевтическая опека). Вполне обоснованно фармакология считается интегральной дисциплиной, которая формирует профессиональное мышление как провизоров (фармацевтов), так и врачей. Поэтому не вызывает сомнений важность постоянного совершенствования методик преподавания фармакологии в учреждениях высшего медицинского и фармацевтического образования, а также определение успешности усвоения материала дисциплины как универсального индикатора эффективности обучения.

Цель исследования - оценить успешность изучения фармакологии будущими специалистами фармации (отечественными и иностранными соискателями высшего образования) по результатам анализа итоговых оценок, баллов за письменный курсовой экзамен и процентов правильных ответов по дисциплине «Фармакология» в рамках лицензионного тестового экзамена КРОК-1 «Фармация», а также разработать процессную модель деятельности по повышению качества подготовки по фармакологии.

Установлено, что в целом отечественные соискатели высшего фармацевтического образования прилагают максимальные усилия к сдаче экзамена КPOK-1, что определено по лучшим результатам экзамена КРОК-1 по сравнению с текущим рейтингом и курсовым экзаменом. Иностранные соискатели высшего фармацевтического образования имеют низкую текущую успеваемость и хуже, чем отечественные, сдают лицензионный экзамен КРОК-1. Корреляционный анализ показал статистически значимые взаимосвязи между текущим рейтингом, курсовым экзаменом и процентом правильных ответов теста KPOK-1 по фармакологии. Однако у отечественных соискателей высшего образования связи между текущим рейтингом и результатом экзамена КPOK-1, а также результатами курсового и лицензионного экзаменов оказались сильнее, чем у иностранных, что может свидетельствовать о большем внимании к фундаментальным знаниям при подготовке и сдаче экзамена КРОК-1. Предложена процессная модель деятельности по улучшению успешности изучения фармакологии и повышения фармакологической компетентности будущих фармацевтов в соответствии со стандартами ISO 9001:2015.

Ключевые слова: фармакология, методы проверки и оценки успеваемости, результаты обучения, соискатели высшего образования, фармацевты, процессная модель деятельности

S. Yu. Shtrygol', V. V. Tsyvunin, I. M. Ryzhenko, L. V. Derymedvid', K. G. Schokina, Ya. O. Butko, V. P. Vereitynova, O. V. Tovchiga, G. V. Belik, O. V. Kudina,

T. O. Kutsenko, A. V. Taran, A. V. Matviichuk, Yu. V. Stoletov, V. A. Ulanova,

O. O. Koiro, L. B. Ivantsyk, M. V. Zupanets

Correlation of indicators of current and exam success in studying pharmacology by applicants for higher pharmaceutical education as an indicator for monitoring the quality of education

In the system of future specialists in pharmacy training, pharmacology occupies a transitional position between basic fundamental (biology, physiology with the basics of human anatomy, pathophysiology, biological chemistry, microbiology with the basics of immunology) and special subjects (pharmacotherapy, clinical pharmacy, pharmaceutical care). Pharmacology is quite justifiably considered an 
integral discipline that shapes the professional thinking of both pharmacists and doctors. Therefore, there is no doubt the importance of continuous improvement of teaching methods of pharmacology in institutions of higher medical and pharmaceutical education, as well as determining the success of mastering the discipline material as an universal indicator of the effectiveness of study.

The aim of the work is to evaluate the success of pharmacology studies by future pharmacy specialists (domestic and foreign applicants for higher education) based on the results of analysis of final grades, scores for a written course exam and percent of correct answers in the discipline "Pharmacology» in the framework of the licensed test exam STEP-1 «Pharmacy», and also to develop a process model of activity for improving the quality of training in pharmacology.

It was established that, in general, domestic applicants for higher pharmaceutical education make maximum efforts to pass the STEP-1 exam, which is determined by the best results of the STEP-1 exam compared to the current rating and course exam. Foreign applicants for higher pharmaceutical education have low current performance and worse than domestic students pass the licensed test exam STEP-1. Correlation analysis showed a statistically significant relationship between the current rating, the course exam and the percentage of correct answers of the STEP-1 test in pharmacology. However, domestic applicants for higher education had a stronger relationship between the current rating and the result of the STEP-1 exam, as well as the results of the course and licensing exams than foreign ones, which may indicate more attention to fundamental knowledge when preparing and passing the STEP-1 exam. A process model of activity for improving the success of pharmacology studies and increasing the pharmacological competence of future pharmacists in accordance with ISO 9001: 2015 is proposed.

Key words: pharmacology; methods of verification and performance assessment; learning outcomes; applicants for higher education; pharmacists; process model of activity.

Надійшла: 28 лютого 2020 p.

Прийнята до друку: 22 квітня 2020 р.

Контактна особа: Штриголь Сергій Юрійович, доктор медичних наук, професор, кафедра фармакології, Національний фармацевтичний університет, буд. 12, вул. Куликівська, м. Харків, 61003. Електронна пошта: shtrygol@ukr.net 